\title{
PEMBANGKIT LISTRIK PIKOTERMAL MATAHARI, KAJIAN AWAL
}

\author{
Aulia*, Darwison, Faisyal Razak, Eka Putra Waldi \\ Jurusan Teknik Elektro, Fakultas Teknik, Universitas Andalas \\ ${ }^{*}$ Corresponding author, e-mail : aulia@ft.unand.ac.id
}

\begin{abstract}
Abstrak - Pembangkit listrik pikotermal matahari (PLTPM) merupakan konsep awal yang masih dalam tahap kajian. Pengujian dan perhitungan tegangan dan arus listrik dilakukan terhadap termoelektrik tunggal, sel termoelektrik terhubung seri dan sel termoeletrik terhubung paralel akibat kenaikan suhu pada sel-sel tersebut. Hasil memperlihatkan bahwa kenaikan suhu sebesar $71{ }^{\circ} \mathrm{C}$ menghasilkan tegangan keluaran 1 volt dan arus 0.1 Amper. Sesuai dengan kaedah hubungan seri dan paralel, hubungan seri mampu melipat gandakan tegangan keluaran dan hubungan paralel melipatkan gandakan arus keluaran untuk tambahan setiap satu keping sel termoelektrik.
\end{abstract}

Kata Kunci : pikotermal, sel termoelektrik, seri, paralel, kenaikan suhu

\begin{abstract}
A Picothermal solar power plant (PLTPM) is an original concept that is still under study. Testing and calculation of voltage and electrical current is carried on a single thermoelectric, thermoelectric cells connected in series and parallel connected thermoelectric cells due to rise in temperature in the cells. The results showed that the increase in temperature of $71^{\circ} \mathrm{C}$ produces 1 volt output voltage and current of 0.1 amperes. In accordance with the principle of series and parallel connection, series connection is able to multiply the output voltage and the parallel connections double the current output for one additional thermoelectric cell chip
\end{abstract}

Keywords : Picothermal, thermoelectric cell and series, parallel, temperature

Copyright (C) 2017 JNTE. All rights reserved

\section{PENDAhuluan}

Pembangkit skala pico (kapasitas $0.5-10 \mathrm{~kW}$ ) sangat dikenal dipergunakan pada pembangkit listrik tenaga air dengan sebutan pikohidro. Ini disebabkan banyaknya tersedia sumber aliran air yang dapat dimanfaatkan dengan kapasitas pico yang bertebaran di banyak negara seperti Indonesia [1, 2], India dan Nigeria [3].

Berbeda dengan pikohidro, ketersediaan energi picotermal masih sangat terbatas dan belum ada pengembang ataupun penyedia jasa yang menawarkan pembangunanya ke masyarakat. Hal ini sangat kontras dengan ketersediaan energi termal matahari yang ada sepanjang tahun dengan jumlah yang melimpah. Kelangkaan pembangkit listrik termal matahari salah satunya disebabkan karena kurangnya perhatian perguruan tinggi dan lembaga riset untuk mengembangkan teknologi yang mendukungnya.

Untuk memanfaatkan energi panas matahari diperlukan suatu teknologi yang dapat memusatkan panas matahari ke satu titik sehingga panas yang terkumpul mampu memanaskan kolektor. Untuk itu, secara umum ada empat jenis teknologi matahari yang dipakai yaitu teknologi tower, teknologi piring parabola, teknologi selimut silindar dan teknologi lensa cembung. Namun tujuan dari teknologi tersebut adalah sama, yaitu agar panas matahari dapat difokuskan seefisien mungkin untuk dijadikan energi listrik. Pada penelitian ini dikaji pemanfaatan energi panas matahari dengan menggunakan teknologi selimut silinder dan sel termoelektrik.

\section{TINJAUAN PUSTAKA}

Fenomena termoelektrik pertama kali ditemukan tahun 1821 oleh ilmuan Jerman Thomas Johan Seebeck. Ia menghubungkan tembaga dan besi dalam sebuah rangkaian. Diantara kedua logam tersebut lalu diberikan jarum kompas. Ketika sisi logam tersebut dipanaskan jarum kompas ternyata bergerak. Diketahui hal ini terjadi karena aliran listrik yang terjadi pada logam menimbulkan medan magnet. 
Medan magnet ini yang menggerakkan jarum kompas[4-8].

Teknologi termoelektrik bekerja dengan mengkonversi energi panas menjadi energi listrik secara langsung (generator termoelektrik), atau sebaliknya dari listrik menghasilkan dingin (pendingin termoelektrik). Untuk menghasilkan listrik, material termoelektrik cukup diletakkan sedemikian rupa dalam rangkaian yang menghubungkan sumber panas dan dingin. Dari rangkaian itu akan dihasilkan sejumlah listrik sesuai dengan jenis bahan yang dipakai[4-10].

Sel termoelektrik secara umum ada dua jenis yaitu efek seebeck dan efek feltier. Efek seebeck ditemukan oleh fisikawan Jerman Thomas Johan Seebeck sewaktu melakukan ekperimen dengan menggunakan dua material logam yang berbeda yaitu tembaga dan besi. Kedua logam itu dirangkai menjadi sebuah sambungan dimana salah satu sisi logam dipanaskan dan satu sisi logam yang lainnya tetap dijaga pada suhu konstan sehingga arus akan mengalir pada rangkaian tersebut. Arus listrik yang mengalir akan mengindikasikan adanya beda potensial antara ujung-ujung kedua sambungan. Jarum kompas yang sebelumnya telah diletakkan diantara dua plat tersebut ternyata mengalami penyimpangan atau bergerak hal ini disebabkan adanya medan magnet yang dihasilkan dari proses induksi elektromagnetik yaitu medan magnet yang timbul karena adanya arus listrik pada logam [4-8, 11-13].

Pada tahun 1834 seorang fisikawan bernama Jean Charle Athanase Peltier, menyelidiki kembali ekperimen dari efek seebeck. Peltier menemukan kebalikan dari fenomena seebeck yaitu ketika arus listrik mengalir pada suatu rangkaian dari material logam yang berbeda terjadi penyerapan panas pada sambungan kedua logam tersebut dan pelepasan panas pada sambungan yang lainya. Pelepasan panas dan penyerapan panas bersesuaian dengan arah arus listrik pada logam. Hal ini dikenal dengan efek peltier [4-8].

Gambar 1 memperlihatkan skematik struktur PLTE yang terdiri susunan elemen tipe-n dan tipe-p [14]. Panas mengalir dari satu sisi dan dibuang ke sisi yang lainya. Aliran panas akan menyebabkan terjadinya aliran panas pada elemen menyebabkan adanya pergerakan elektron pada elemen PLTE akibat ada beda tegangan yang melewati sambuangan termoelektrik. Besarnya tegangan yang dihasilkan sebanding dengan gradien temperatur. Bahan semikonduktor yang digunakan adalah bahan semikonduktor ekstrinsik.

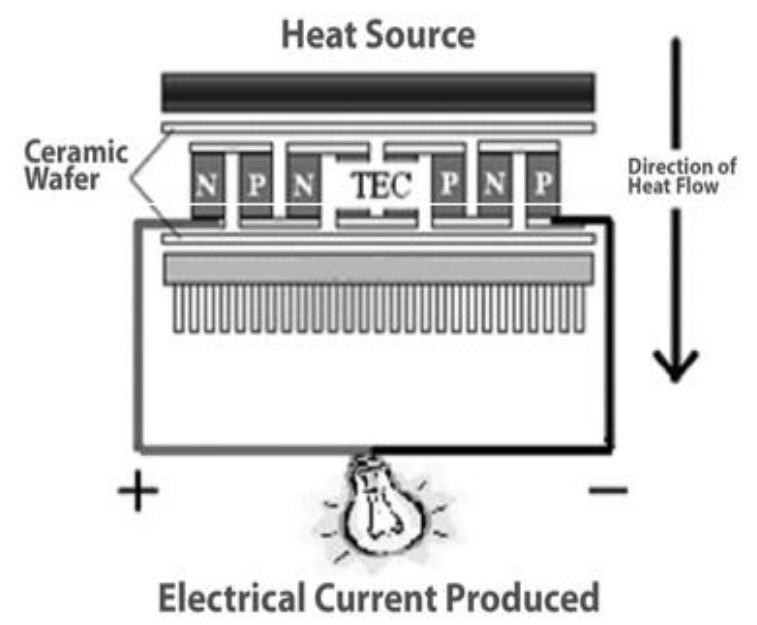

Gambar 1. Diagram aliran arus akibat beda suhu pada elemen PLTE

Energi yang dikeluarkan oleh sinar matahari sebenarnya hanya diterima oleh permukaan bumi sebesar $69 \%$ dari total energi pancaran matahari. Suplai energi surya dari sinar matahari yang diterima oleh permukaan bumi sangat luas biasa, besarnya yaitu mencapai 3 X 1024 Joule pertahun. Jumlah energi tersebut setara dengan 10000 kali konsumsi energi di seluruh dunia saat ini [15]. Dengan kata lain, dengan menutupi $0,1 \%$ saja permukaan bumi dengan efiseiensi $10 \%$ sudah mampu untuk menutupi kebutuhan energi di seluruh dunia saat ini.

Energi matahari diperoleh dari cahaya panas yang merupakan komponen dari panas matahari. Energi ini bisa diubah menjadi energi listrik. Secara global, matahari menyediakan 10.000 kali energi bumi yang dapat di memanfaatkan siapapun secara gratis, dan merupakan salah satu sumber energi alternatif yang potensial untuk dikelola dan dikembangkan lebih lanjut, terutama bagi negara-negara tropis seperti Indonesia $[16,17]$.

Panas matahari memberikan suhu yang sesuai untuk kelangsungan hidup organisme di Bumi. Bumi juga menerima energi matahari dalam jumlah yang sesuai untuk membuat air tetap berbentuk cair untuk penyokong kehidupan. Selain itu panas matahari memungkinkan adanya angin, siklus hujan, cuaca, dan iklim. Cahaya matahari dimaanfaatkan secara langsung oleh tumbuhan berklorofil untuk melangsungkan 
fotosintesis, sehingga tumbuhan dapat tumbuh serta menghasilkan oksigen sebagai sumber pangan bagi hewan dan manusia.

Pembangkit listrik tenaga matahari adalah modal baru pembangkit listrik dengan sumber energi terbarukan. Salah satu jenis pembangkit listrik ini terdiri dari kaca-kaca besar atau panel yang akan menerima cahaya matahari dan memantulkanya untuk difokuskan ke satu titik. Panas yang terfokus kemudian digunakan untuk menghasilkan uap panas bertekanan yang akan dipakai untuk menjalankan turbin sehingga energi listrik dapat dihasilkan.

\section{METODOLOGI}

Gambar 2 memperlihatkan skematik reflektor dan kolektor pembangkit listrik tenaga picotermal matahari (PLTPM) yang akan dikembangkan yang terdiri dari reflektor dan konsentrator atau kolektor panas. Reflektor merupakan bagian yang penting dalam proses pengumpulan energi radiasi matahari yang berfungsi memantulkan radiasi panas matahari ke kolektor. Reflektor terbuat dari lembaran seng yang melengkung berbentuk kulit silinder dengan ukuran jari-jari tertentu. Bahan reflektor bisa terbuat dari dari cermin lengkung atau dari kayu atau aluiminium yang dilapisi dengan lapisan tipis aluminium (alummunium foil) agar hasil pantulan cahaya matahari lebih maksimal. Pada penelitian ini dimensi reflektor adalah sebesar 120 X $40 \mathrm{~cm}$ mengikuti panjang dari penerima panas matahari dengan total $40 \mathrm{~cm}$ meter.

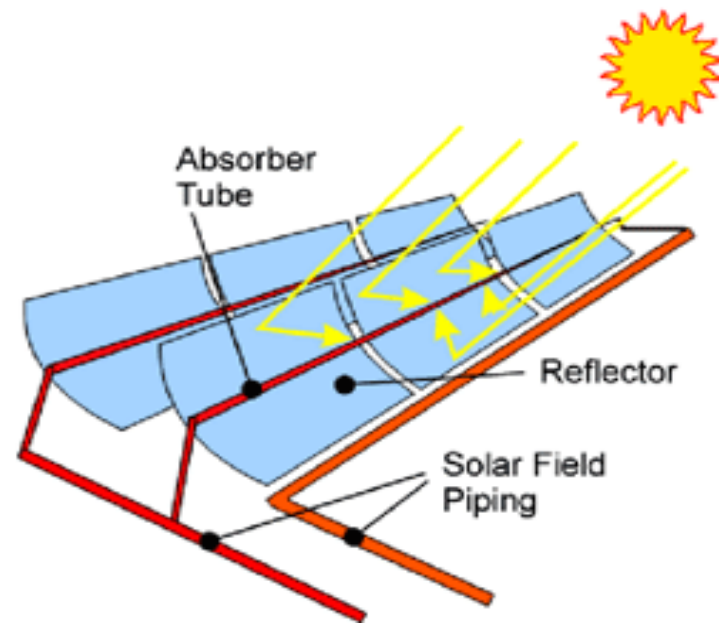

Gambar 2. Rancangan reflektor termal matahari sepertiga kulit tabung
Kolektor adalah metal yang berbentuk silinder atau setengah silinder yang juga perfungsi sebagai penyangga konsutruksi PLTPM. Panas yang diterima dipergunakan untuk memanaskan salah satu permukaan dari elemen termoelektrik yang ditempelkan ke kolektor yang berfungsi sebagai generator PLTPM. Pada sisi bersuhu rendah dipasang balok aliran air agar tetap pada kondisi temperatur yang stabil lebih kurang $30{ }^{\circ} \mathrm{C}$.

\section{HASIL DAN PEMBAHASAN}

Pada pembahasan berikut diperlihatkan beberapa hasil pengujian awal yang telah dilakukan. Pengujian dilakukan untuk melihat pengaruh perubahan suhu terhadap satu buah dan beberapa buah keping sel termoelektrik yang dipasang seri dan paralel.

Gambar 3 memperlihatkan perubahan besar arus dan tegangan akibat perubahan suhu dari sebuah sel termoelektrik. Arus dan tegangan naik secara linear seiring dengan meningkatnya kenaik suhu mulai dari $0{ }^{\circ} \mathrm{C}$ sampai $71{ }^{\circ} \mathrm{C}$. Arus listrik naik sebesar $0.1 \mathrm{~mA}$ dan tegangan naik sebesar 1 volt

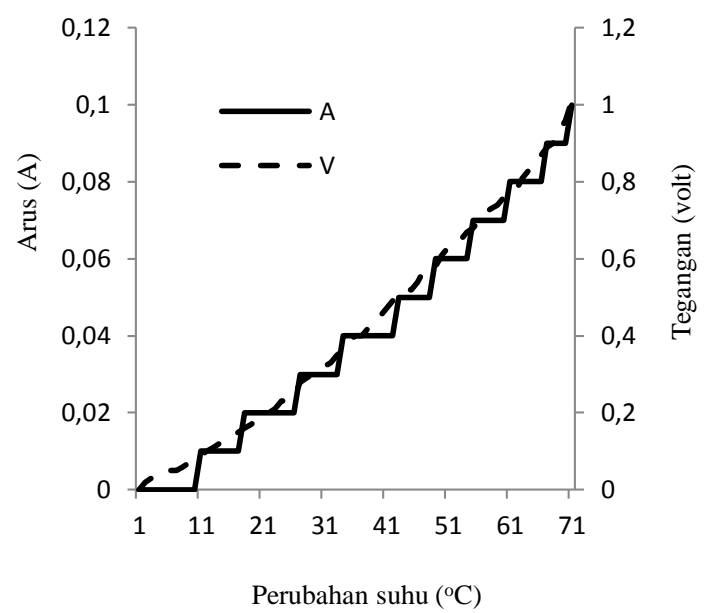

Gambar 3. Pengaruh perubahan suhu terhadap besar aru dan tegangan terhadap satu keping sel termoelektrik

Gambar 4 memperlihatkan sel ternoelektrik yang terhubung seri. Tegangan maksimum terus meningkat seiring dengan bertambahnya jumlah sel termoelektrik dari 2-3 keping. Peningkatan tegangan mencapai 2 kali lipat dengan kenaikan suhu $70^{\circ}$ C. Arus juga mengalami sedikit kenaikan pada rangkaian terhubung seri. 


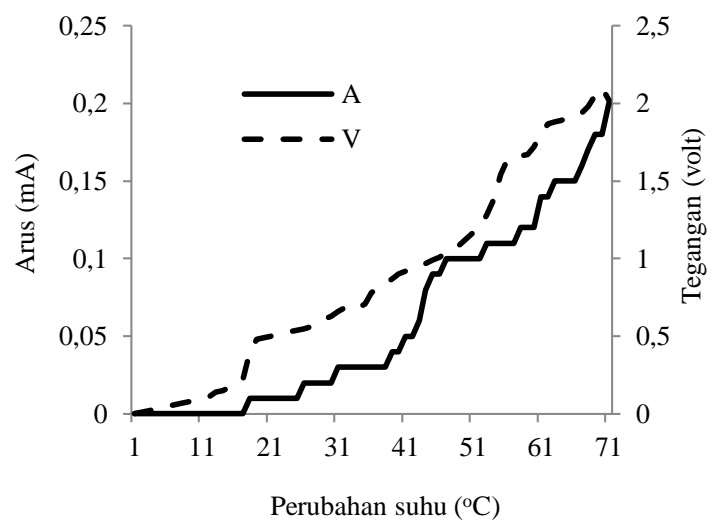

(a)

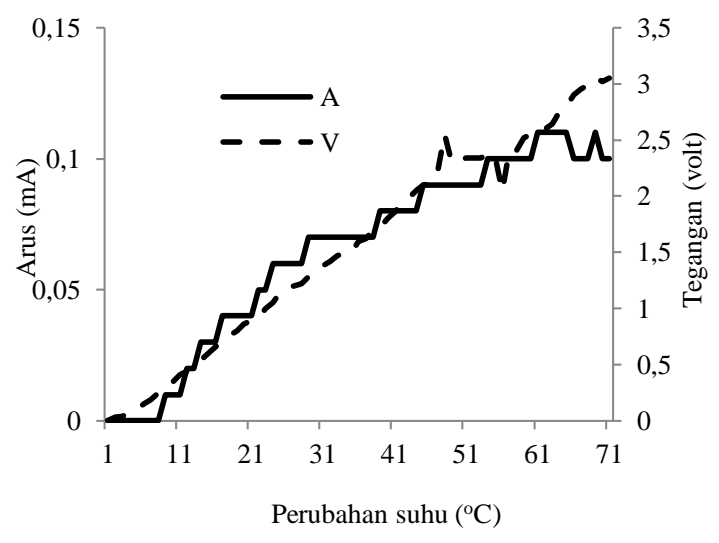

(b)

Gambar 4. Pengaruh perubahan suhu terhadap besar arus dan tegangan terhadap sel termoelektrik yang terhubung seri, (a). dua keping, (b). tiga keping

Gambar 5 memperlihatkan pengaruh perubahan suhu terhadap sel termoelektrik yang terhubung paralalel. Tegangan relative stabil pada nilai 1 Volt sedangkan nilai arus mengalami kenaikan dua kali lipat, dari $1 \mathrm{~mA}$ menjadi $2 \mathrm{~mA}$ untuk kenaikan suhu $71^{\circ} \mathrm{C}$.

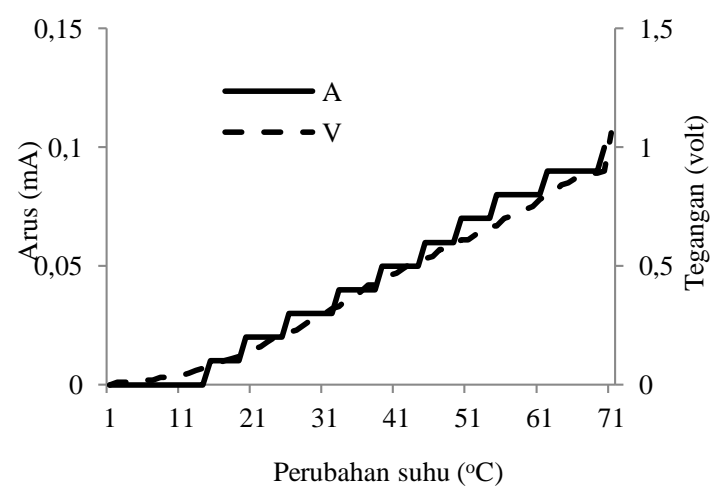

(a)

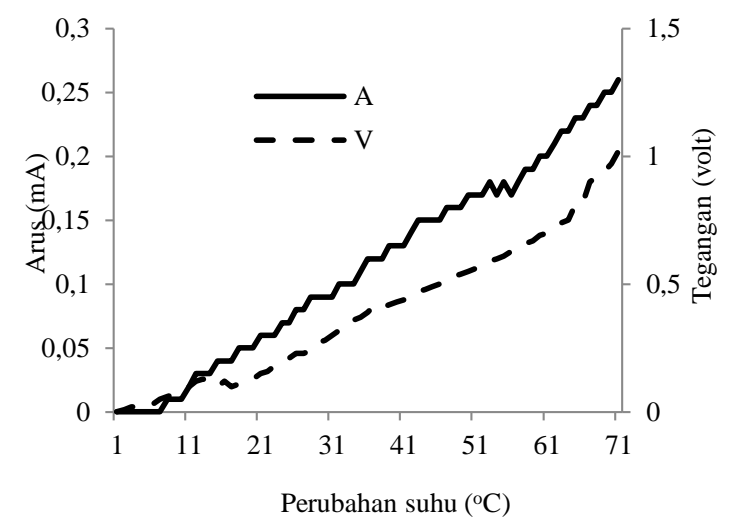

(b)

Gambar 5. Pengaruh perubahan suhu terhadap besar arus dan tegangan terhadap sel termoelektrik yang terhubung paralel, (a). dua keping, (b). tiga keping

\section{UCAPAN TERIMA KASIH}

Terima ditujukan kepada Fakutas Teknik Universitas Andalas yang telah membantu sebagian pendanaan penelitian ini dengan kontrak No. 02/UN.16.09.D/PL/2016.

\section{KESIMPULAN}

Penelitian awal pembangkit picotermal telah dilaksanakan konsep yang dikaji memperlihatkan bahwa PLTPM dapat dikembangkan di masa datang sebagai pembangkit listrik alternatif. Hasil pengujian terhadap sel termoelektrik yang dilengkapi dengan hasil perhitungan memperlihatkan bahwa rangkaian seri dan paralel sel termoelektrik mempengaruhi nilai arus dan tegangan keluaran. Kenaikan suhu $71{ }^{\circ} \mathrm{C}$ baru menghasilkan tegangan 1 volt dan arus $0.1 \mathrm{~A}$.

\section{DAFTAR PUSTAKA}

[1] R. I. Tribowo and A. Haryanto, "Analysis of water source availability estimation for picohydro electric generator (Case study in Gunung Tua village, sub district of Cijambe, district of Subang, Province of West Java, Indonesia)," in 2014 2nd International Conference on Technology, Informatics, Management, Engineering \& Environment, 2014, pp. 363-368. 
[2] K. S. Gautama, D. A. Triatmojo, F. Pambudi, D. Yusdinar, K. Asrimaya, R. Azhar, et al., "PALAPA - Distributed power generation for the development of underdeveloped villages in Indonesia," in Proceedings of the 2011 International Conference on Electrical Engineering and Informatics, 2011, pp. 1-4.

[3] K. O. Lawal, "Hydro-based, renewable hybrid energi sytem for rural/remote electrification in Nigeria," in 2015 Clemson University Power Systems Conference (PSC), 2015, pp. 1-6.

[4] J. Henderson, "Analysis of a Heat Exchanger-Thermoelectric Generator System," 1979.

[5] T. M. Tritt and M. A. Subramanian, "Thermoelectric Materials, Phenomena, and Applications: A Bird's Eye View," MRS Bulletin, vol. 31, pp. 188-198, 2011.

[6] S. Sunaryo and U. B. Sudibyo, "Penggunaan Pendingin Thermoelectric pada Bts Indoor untuk Mengurangi Konsumsi Energi Listrik," Prosiding Semnastek, 2015.

[7] A. Mukminin, P. N. Rahman, P. A. Wibowo, and A. Solikhin, "'Threger" Thermoelectric Charger Sebagai Alat Konversi Energi Panas Buang Motor Bakar Menjadi Sumber Energi Listrik," 2014.

[8] A. Gitrio, R. Yuli, and A. R. Khairul, "Karakteristik Pembangkitan Thermoelectric Menggunakan Enam Buah Modul Peltier Secara Seri dan Paralel," Universitas Bengkulu, 2015.

[9] L. I. Anatychuk and R. V. Kuz, "Materials for Vehicular Thermoelectric Generators," Journal of Electronic Materials, vol. 41, pp. 1778-1784, Jun 2012

[10] L. I. Anatychuk, "Original thermoelectric development of physical concepts, materials and related technologies and applications," in Thermoelectrics, 2001. Proceedings ICT 2001. XX International Conference on, 2001, pp. 35-41.

[11] V. I. Kubov, Y. Y. Dymytrov, and R. M. Kubova, "LTspice-model of thermoelectric Peltier-Seebeck element," in 2016 IEEE 36th International Conference on Electronics and
Nanotechnology (ELNANO), 2016, pp. 47-51.

[12] S. Ouitrakul, "Preliminary experiment for electricity generation using Peltier modules," in Electrical Engineering/Electronics, Computer, Telecommunications and Information Technology (ECTI-CON), 2014 11th International Conference on, 2014, pp. 15.

[13] W. C. White, "Some experiments with peltier effect," Electrical Engineering, vol. 70, pp. 589-591, 1951.

[14] L. I. Anatychuk, V. V. Razinkov, Y. Y. Rozver, and V. Y. Mikhailovsky, "Thermoelectric generator modules and blocks," in Thermoelectrics, 1997. Proceedings ICT '97. XVI International Conference on, 1997, pp. 592-594.

[15] D. Susilo, "Peningkatan Daya Keluaran Sel Surya Dengan Penjejak Matahari dan Pemantulan Cahaya Matahari Sebagai Sumber Daya Pendukung Perusahaan Listrik Negara (Pln) Sub Judul: Penjejak Matahari Berbasis Sensor," EEPIS Final Project, 2010.

[16] M. A. Drs. Kandi, Drs. Yamin Winduono, M.Pd, "Energi dan Perubahannya," 2009.

[17] R. Rachmat, RaymondSutanto, "Energi," 2016.

\section{Biodata Penulis}

Aulia, lahir di desa Batuhampar, Payakumbuh, Sumatera Barat pada tahun 1968. Menamatkan jenjang pendidikan S1 di UNSRI, Indralaya, Sumatera Selatan tahun 1996, jenjang pendidik S2 dan S3 di UTM, Johor, Malaysia pada tahun 2009 dan 2016. Sekarang bekerja sebagai dosen di Jurusan Teknik Elektro Universitas Andalas. Ketertarikan terhadap penelitian adalah di bidang teknik tegangan tinggi dan energi baru dan terbarukan.

Darwison, lahir tahun 1964 di Payakumbuh Sumatera Barat. dan menamatkan jenjang pendidikan S1 tahun 1992 dari ITS, Surabaya dan jenjang pendidikan S2 di UGM, Jogyakarta tahun 2001. Bekerja sebagai dosen tetap di Jurusan Teknik Elektro Universitas Andalas dan sekarang sedang menyelesaikan jenjang pendidikan S3 di Universtias yang sama. Ketertarikan penelitian adalah di bidang tegangan tinggi, mekatronika, signal dan sensor. 
Faisyal Razak, lahir di Payakumbuh dan sekarang sedang menyelesaikan jenjang pendidikan S1 di Jurusan Teknik Elektro Univesitas Andalas di bawah bimbingan
Ir. Darwison, MT dan Aulia, Ph.D. Ketertarikan riset adalah bidang sensor dan energi baru dan terbarukan. 